\title{
Problematika Anak di Luar Nikah Ditinjau dari Maqasid As-Syari'ah
}




\section{UNDANG-UNDANG REPUBLIK INDONESIA NOMOR 28 TAHUN 2014 TENTANG \\ HAK CIPTA \\ Lingkup Hak Cipta}

Pasal 1 Ayat 1 :

1. Hak Cipta adalah hak eksklusif pencipta yang timbul secara otomatis berdasarkan prinsip deklaratif setelah suatu ciptaan diwujudkan dalam bentuk nyata tanpa mengurangi pembat-asan sesuai dengan ketentuan peraturan perundang-undangan.

\section{Ketentuan Pidana:}

Pasal 113

1. Setiap Orang yang dengan tanpa hak melakukan pelanggaran hak ekonomi sebagaimana dimaksud dalam Pasal 9 ayat (1) huruf i untuk Penggunaan Secara Komersial dipidana dengan pidana penjara paling lama 1 (satu) tahun dan/atau pidana denda paling banyak Rp100.000.000 (seratus juta rupiah).

2. Setiap Orang yang dengan tanpa hak dan/atau tanpa izin Pencipta atau pemegang Hak Cipta melakukan pelanggaran hak ekonomi Pencipta sebagaimana dimaksud dalam Pasal 9 ayat (1) huruf c, huruf d, huruf f, dan/atau huruf h untuk Penggunaan Secara Komersial dipidana dengan pidana penjara paling lama 3 (tiga) tahun dan/atau pidana denda paling banyak Rp500.000.000,00 (lima ratus juta rupiah).

3. Setiap Orang yang dengan tanpa hak dan/atau tanpa izin Pencipta atau pemegang Hak Cipta melakukan pelanggaran hak ekonomi Pencipta sebagaimana dimaksud dalam Pasal 9 ayat (1) huruf a, huruf b, huruf e, dan/atau huruf g untuk Penggunaan Secara Komersial dipidana dengan pidana penjara paling lama 4 (empat) tahun dan/atau pidana denda paling banyak Rp1.000.000.000,00 (satu miliar rupiah).

4. Setiap Orang yang memenuhi unsur sebagaimana dimaksud pada ayat (3) yang dilakukan dalam bentuk pembajakan, dipidana dengan pidana penjara paling lama 10 (sepuluh) tahun dan/atau pidana denda paling banyak Rp4.000.000.000,00 (empat miliar rupiah).

\section{Pasal 114}

Setiap Orang yang mengelola tempat perdagangan dalam segala bentuknya yang dengan sengaja dan mengetahui membiarkan penjualan dan/atau penggandaan barang hasil pelanggaran Hak Cipta dan/ atau Hak Terkait di tempat perdagangan yang dikelolanya sebagaimana dimaksud dalam Pasal 10, dipidana dengan pidana denda paling banyak Rp100.000.000,00 (seratus juta rupiah). 


$$
\begin{gathered}
\text { Kalijunjung Hasibuan SHI., M. Sy } \\
\text { Dr. Ali Hamzah, M. Ag }
\end{gathered}
$$

\section{Problematika Anak di Luar Nikah Ditinjau dari Maqasid As-Syari'ah}




\section{Problematika Anak di Luar Nikah Ditinjau dari Maqasid As-Syari'ah \\ @Kalijunjung@Alihamzah}

Penulis

Penyelaras Aksara

Tata Letak

Desain Cover
: Kalijunjung Hasibuan SHI., M.Sy

Dr. Ali Hamzah, M. Ag

: Nurrahmawati

: Nur Azizah

: Bintang W Putra

\section{Penerbit:}

\section{Bintang Pustaka Madani}

(CV. Bintang Surya Madani)

Jl. Wonosari Km 8.5, Dukuh Gandu Rt. 05, Rw. 08

Sendangtirto, Berbah, Sleman, Yogyakarta 57773

Telp. 4358369 . Hp. 085865342317

Email: redaksibintangpustaka@gmail.com

Facebook: Penerbit Bintang Madani

Instagram: @bintangpustaka

Website: www.bintangpustaka.com

www.pustakabintangmadani.com

Problematika Anak di Luar Nikah Ditinjau dari Maqasid As-Syari'ah

Kalijunjung Hasibuan, Ali Hamzah

Cetakan Pertama, November 2020

Bintang Pustaka Madani Yogyakarta

$\mathrm{x}+130$ hal : $15.5 \times 23 \mathrm{~cm}$

ISBN :

Dicetak Oleh:

Percetakan Bintang 085865342319

Hak cipta dilindungi undang-undang All right reserved

Isi di luar tanggung jawab percetakan 


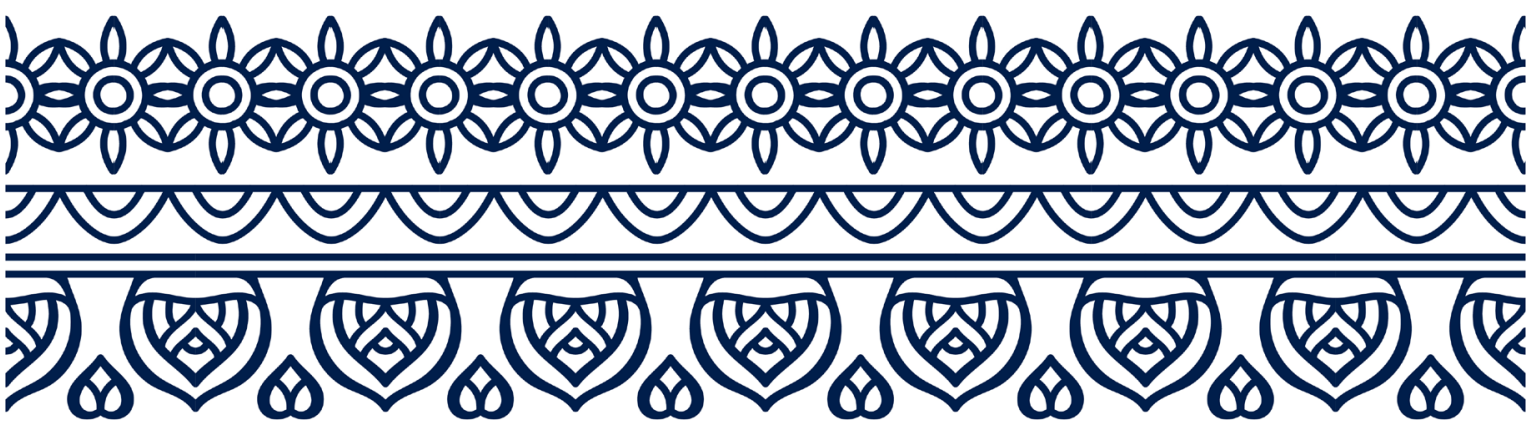

\section{KATA PENGANTAR}

Segala puji dipersembahkan kehadirat Allah swt yang telah memberikan bermacam-macam nikmat kepada kita. Shalawat beriring salam dipersembahkan kepada Nabi Muhammad saw sebagai Rasul akhir zaman dan rahmatan lil'alamin.

Dengan rahmat dan hidayah Allah, penulis dapat menyusun buku ini berjudul: "PROBLEMATIKA ANAK DI LUAR NIKAH DITINJAU DARI MAQASID AS-SYARI'AH”

Dalam penyelesaian buku ini penulis tidak luput dari kesulitan, terutama sekali dalam pengumpulan data. Oleh karena itu wajarlah kiranya penulis mengucapkan terimakasih kepada setiap yang ikut dalam penyelesaian buku ini di masa yang lalu :

1. Prof Dr. Mahdini MA selaku Diretur Pasca sarjana Universitas Islam Negeri Sultan Syarif Kasim Riau yang telah menerima judul tesis ini untuk diteliti.

2. Dr. Mawardi M.Saleh,MAselaku yang telah arahan kepada penulis 
3. Prof.Dr. M. Arrafi'e Abduh, M.Ag, yang telah memberikan arahan terhadap penulisan buku penulis

4. Dr. Mawardi M.Saleh,M yang telah banyak meluangkan waktu, pikiran dan tenaga dengan memberikan pengarahan kepada penulis sampai buku ini terselesaikan.

5. Ibunda tercinta dan saudara/i, yang telah banyak memberikan dukungan, materi, moril serta do'a dalam setiap sholatnya, agar penulis dapat menyelesikan buku ini.

6. Teman-teman seperjuangan akantan 2010 yang telah banyak mendukung penulis dalam menyelesaikan buku ini.

7. Banyak lagi mereka yang sungguh besar jasanya kepada penulis yang tidak dapat disebutkan namanya satu persatu.

8. Akhirnya penulis mengharapkan tegur sapa, saran saran dan kritik sehat yang bersifat membangun dari segenap cerdik pandai dan cendikiawan demi kesempurnaan tesis ini selanjutnya, semoga ada manfaatnya bagi masyarakat bangsa dan Negara.

9. Kepada Allah swt kita berserah diri , agar senantiasa diberikan taufiq dan hidayah Nya kepada kita semua, amin

Sibuhuan, Oktober 2020

Penulis 
Ahkam al-Syari'ah------------------------------------------- 32

BAGIAN III STATUS DAN KEDUDUKAN ANAK --35
A. Anak dan Statusnya dalam Hukum Islam 35
B. Kedudukan Anak menurut Undang-Undang

Indonesia

C. Konsep Maqashid Syariah Tentang Memelihara

Keturunan

D. Sejarah Berdirinya Mahkamah Konstitusi

E.Visi dan Misi

F. Struktur Organisasi Mahkamah Konstitusi

G. Ruang Lingkup dan Wewenang Mahkamah

Konstitusi

\section{BAGIAN IV HASIL KAJIAN DAN PEMBAHASAN-53}

A. Status Anak di luar Nikah dan yang tidak Tercatat 53

1. Pendapat Ulama Fiqih---------------------------------- 53

2. Pendapat Majelis Ulama Indonesia (MUI) --------- 70

3. Pendapat Mahkamah Konstitusi--------------------- 72

B. Status Anak di luar Nikah dan yang tidak tercatat dalam Konteks Maqâshid al-Syar'iyyah 90

C. Analisis $-95$

1. Pendapat Ulama Fiqih----------------------------------- 95

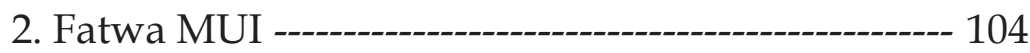

3. Mahkamah Konstitusi ----------------------------------- 108

BAGIAN V PENUTUP ---------------------------------------117
A. Kesimpulan
B. Saran-Saran- 
Kalijunjung Hasibuan SHI., M.Sy dan Dr. Ali Hamzah, M.Ag

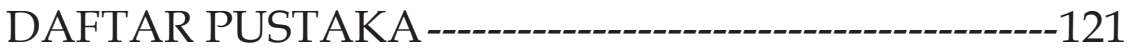

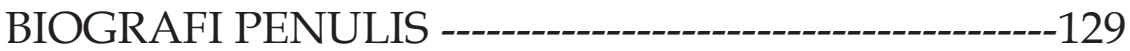





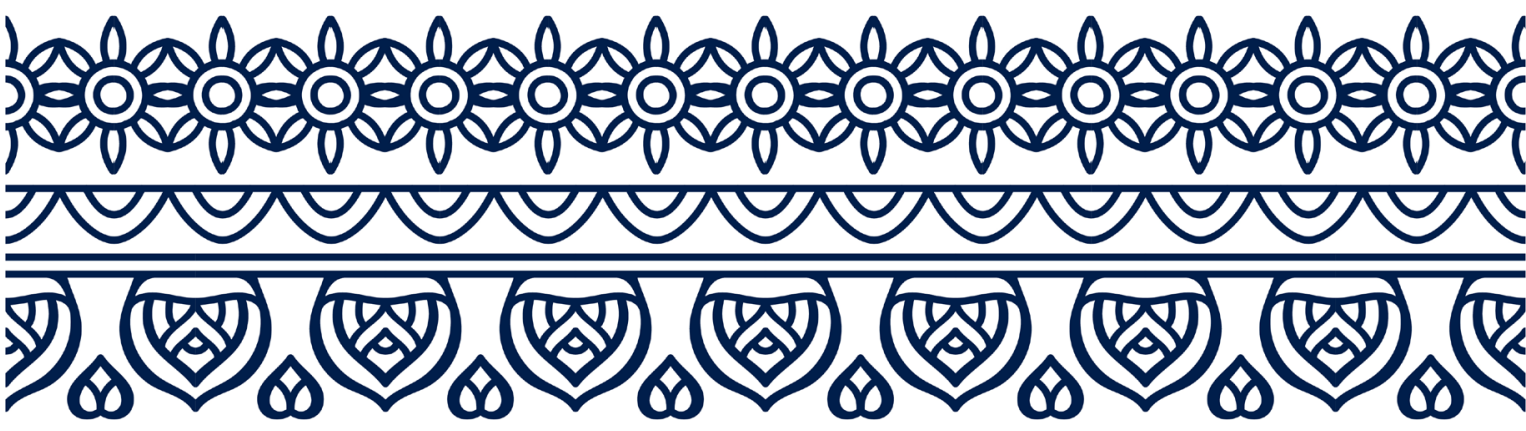

\section{BAGIAN I}

\section{PENDAHULUAN}

\section{A. Latar Belakang Masalah}

Perkawinan adalah jalan yang dipilih Allah untuk melestarikan keturunan. Dikeluarkannya Adam dan Hawa dari Surga untuk kemudian ditempatkan di bumi dapat dikatakan sebagai cikal bakal penciptaan manusia oleh Allah SWT. Manusia menurut ajaran agama Islam adalah sebagai pemimpin atau wakil Tuhan di muka bumi. Dalam istilah agama fungsi manusia yang demikian disebut "Khalifah". Misi manusia sebagai khalifah pada pokoknya adalah memelihara dan menciptakan kemaslahatan manusia dalam hubungannya dengan alam semesta, serta memelihara keluarnya dan melindungi serta memberi nafkah sebagaimana firman Allah dalam surat At-Tahrim ayat: 6 yang berbunyi:

"Hai orang-orang yang beriman, peliharalah dirimu dan keluargamu dari api neraka yang bahan bakarnya adalah manusia dan batu; penjaganya malaikat-malaikat yang kasar, keras, dan tidak mendurhakai Allah terhadap apa yang diperintahkan-Nya kepada mereka dan selalu mengerjakan apa 


\section{yang diperintahkan" (Q.S.66:6)}

Sayyid Sabiq menulis dalam bukunya Fikih Sunnah : "Perkawinan adalah suatu cara yang dipilih Allah sebagai jalan bagi manusia untuk beranak, berkembang biak dan melestarikan hidupnya, setelah masing-masing pasangan siap melakukan peranannya yang positif dalam mewujudkan tujuan perkawinan”. ${ }^{2}$ Tuhan tidak mau menjadikan manusia itu seperti makhluk lainnya, yang hidup bebas mengikuti nalurinya dan berhubungan antara jantan dan betina secara anarki, dan tidak ada satu aturan. Tetapi demi menjaga kehormatan dan martabat kemuliaan manusia, Allah membuat hukum sesuai dengan martabatnya.

Sehingga hubungan antara laki-laki dan perempuan diatur secara terhormat dan berdasarkan saling meridhai, dengan upacara ijab dan qabul sebagai lambang dari adanya rasa ridha-meridhai, dan dengan dihadiri para saksi yang menyaksikan kalau pasangan laki-laki dan perempuan itu telah saling terikat. Perkawinan menurut syari'at Islam setidak-tidaknya akan :

1. Membuat hubungan antara laki-laki dan perempuan menjadi terhormat dan saling meridhai.

2. Memberikan jalan yang paling sentosa pada sebagai naluri manusia, memelihara keturunan dengan baik dan menghindarkan kaum wanita dari penindasan kaum laki-laki.

3. Membuat pergaulan suami-isteri berada dalam naungan naluri keibuan dan kebapakan, sehingga akan melahirkan anak keturunan yang baik sebagai generasi penerus misi kekhalifahan.

4. Menimbulkan suasana yang tertib dan aman dalam kehidupan sosial. ${ }^{3}$

Anak hasil dari suatu perkawinan merupakan bagian yang sangat penting

1 Departemen Agama Republik Indonesia, Al-Qur'an Dan Terjemah, (Semarang: Toha Putra, 2005), h. 820

2 Sayyid Sabiq, Fikih Sunnah ditejemahkan oleh Mohammad Thalib, (Bandung : PT. al-Ma'arif, 1980), Jilid 6, Cet 15, h. 7.

3 M. Zuffan Sabrie, Analisa Hukum Islam Tentang Anak Luar Nikah, (Jakarta : Departemen Agama RI, 1998), h. 7-8 
kedudukannya dalam suatu keluarga menurut hukum Islam. Sebagai amanah Allah, maka orang tuanya mempunyai tanggung jawab untuk mengasuh, mendidik dan memenuhi keperluannya sampai dewasa. Namun tidak semua anak lahir dari perkawinan yang sah, bahkan ada kelompok anak yang lahir sebagai akibat dari perbuatan zina. Anak-anak yang tidak beruntung ini oleh hukum dikenal dengan sebutan anak luar nikah.

Anak yang lahir diluar nikah, kedudukan didalam hukum, yang berkaitan dengan hak-hak keperdataan mereka tentu saja amat tidak menguntungkan, padahal kehadiran mereka di dunia ini adalah atas kesalahan dan dosa orangorang yang membangkitkan mereka. Menurut Undang-undang Perkawinan dan Kompilasi Hukum Islam, anak yang sah adalah anak yang dilahirkan dalam atau akibat perkawinan yang sah, meskipun anak tersebut lahir dari perkawinan wanita hamil yang usia kandungannya kurang dari enam bulan lamanya sejak ia menikah resmi. Hal ini diatur dalam Undang-undang No. 1 Tahun 1974 Pasal 42 : "Anak yang sah adalah anak yang dilahirkan dalam atau akibat perkawinan yang sah". Dan dalam Kompilasi Hukum Islam Pasal 99 : Anak yang sah adalah :

a. Anak yang dilahirkan dalam atau akibat perkawinan yang sah.

b. Hasil pembuahan suami isteri yang sah di luar rahim dan dilahirkan oleh isteri tersebut ${ }^{4}$.

Sedangkan menurut hukum Islam anak baru dianggap sah dan mempunyai hubungan nasab dengan Bapaknya bila perkawinan wanita hamil yang usia kandungannya minimal enam bulan dari perkawinan resminya. Di luar ketentuan itu adalah anak dianggap sebagai anak tidak sah atau anak zina. Selain itu sebuah perkawinan adalah sah apabila dilakukan menurut hukum masingmasing agamanya dan kepercayaannya itu (pasal 2 ayat 1 UU Perkawinan). Ini berarti bahwa jika suatu perkawinan telah memenuhi syarat dan rukun nikah atau ijab kabul telah dilaksanakan (bagi umat Islam) atau pendeta/pastur telah melaksanakan pemberkatan atau ritual lainnya (bagi yang non muslim), maka

4 Undang-undang No. 1 Tahun 1974 Pasal 42, 
perkawinan tersebut adalah sah, terutama di mata agama dan kepercayaan masyarakat. Karena sudah dianggap sah, akibatnya banyak perkawinan yang tidak dicatatkan. ${ }^{5}$

Namun jika dilihat lagi ke arah maqashid al-syariah yang kita rujuk kepada pendapat al-Syâtibi. Dalam maqashid al-syariah tentu harus menempatkan buah pikir al-Syâtibi sebagai fokus perhatian, karena beliaulah yang merupakan icon bagi konsep maqashid al-syariah dalam jagat wacana teori hukum Islam. Dalam karyanya al-Muwâfaqât, al-Syâtibi menggunakan istilah yang berbeda-beda sehubungan dengan isu Maqâshid al-Syarî̀ah, yakni berupa istilah maqashid alalsyariah, maqashid al-syari'ah fi al-Syarîah, dan maqashid min Syar'i al-hukum. Meskipun demikian, semua itu mengandung pengertian yang sama, yakni tujuan, arah sasaran, dan dasar pijakan bagi hukum yang ditetapkan oleh Allah swt. ${ }^{6}$ Uraian berikut ini sepenuhnya merujuk kepada magnum opus al-Syâttibi tersebut. Dalam proposisi utama yang diutarakannya, al-Syâtibi menegaskan bahwa sesungguhnya Syariah/hukum Islam itu bertujuan mewujudkan maslahah bagi manusia, baik di dunia maupun di akhirat. Pada bagian lain, beliau mengungkapkan: "Hukum-hukum ditetapkan untuk mewujudkan maslahah bagi umat manusia."” Dengan demikian, jelaslah bahwa al-Syâtibi memandang

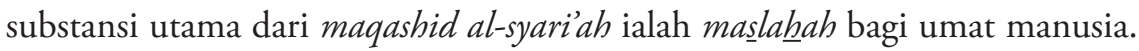
Oleh karena itu, isu mas $\underline{\text { lahah }}$ menjadi fokus analisis penting dalam rangka memahami maqashid al-alsyari'ah.

Menurut pendapat al-Syâtibi, pembebanan hukum oleh Syariah bermuara kepada sasaran terpeliharanya tujuan-tujuan Syariah. Adapun tujuan-tujuan Syariah ini tidak melebihi tiga macam, yaitu (1) darûriyyah, (2) hâjjiyyah, dan (3) tahsinniyyah. Yang dimaksud darûriyyah ialah sesuatu yang tidak boleh tidak ada demi tegaknya kehidupan, di mana manakala ia tidak terwujud, maka tidak dapat terwujud pula kehidupan, bahkan, akan rusak kehidupan secara keseluruhan. Darûriyyah itu mencakup 5 (lima) hal, yaitu perlindungan/penghormatan

5 Muhammad Fu'ad Syakit, Perkawinan Terlarang, (Jakarta: CV. Cendiekia Sentra Muslim, 2002), h.58-59

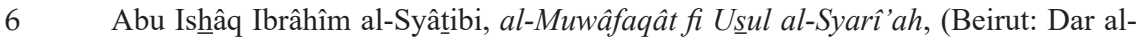
Kutub al-'Ilmiyyah, t.th.), Buku I, Juz ke-2, h. 3.

$7 \quad$ Ibid, h. $4-7$ 
agama, perlindungan/penghormatan jiwa, perlindungan/penghormatan akal budi, perlindungan/penghormatan keturunan, dan perlindungan/penghormatan harta kekayaan. Menurut pandangan al-Syâtibi, maslahahah dibangun dengan beralaskan fondasi perlindungan/penghormatan kelima macam hal tersebut (al-kulliyyât al-khams, al-maqâshid al-khamsah).

Dalam urusan keduniaan tidak ada sesuatu yang secara murni mengandung

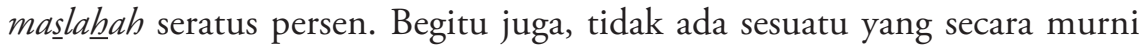
mengandung mafsadah seratus persen. ${ }^{8}$ Maka, dalam urusan keduniaan, maslahah dan mafsadah harus dipertimbangkan beradasarkan aspek dominan yang dikandungnya. Apabila kandungannya didominasi aspek masla $\underline{a} a h$ maka ia merupakan masla $\underline{h} a h$. Apabila kandungannya didominasi aspek mafsadah maka ia merupakan mafsadah. ${ }^{9}$ Dalam pandangan al-Syâtibi, yang dimaksud hâajiyyah ialah sesuatu yang dibutuhkan dari sisi kemampuannya untuk mendatangkan kelapangan dan menghilangkan kesempitan/kesukaran ( raf al-haraj wa almasyaqqah). Apabila hâjijyyah tidak diperhatikan maka akan muncul kesukaran dan kesusahan, tetapi tidak sampai menimbulkan kerusakan terhadap darûriyyah. Yang termasuk hâjjiyyah, misalnya, segala bentuk rukhsah, biasanya terdapat pada urusan ibadah,kebiasaan-kebiasaan masyarakat, muamalat, dan kepidanaan. Dalam urusan ibadat, misalnya segala rukhsah dan bay salam. ${ }^{10}$ Hâjjiyyah sesungguhnya hadir dalam rangka mendukung sempurnanya darûriyyah. ${ }^{11}$ Menurut pendapat al-Syâtibi, tahsininiyyah ialah sesuatu yang berkenaan dengan makârim al-akhlâq, etika dan etiket. ${ }^{12}$ A Tạhsinniyyah sesungguhnya hadir dalam

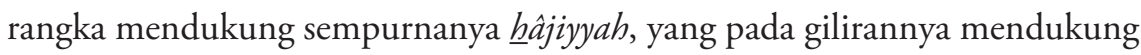
sempurnanya darûriyyah. Ketiadaan tahsiniyyah tidak mendatangkan kerusakan

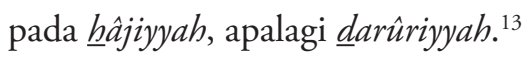

Dalam pandangan al-Syâtibi, al-Syârì-dalam program tasyrî-nya-bertujuan menegakkan maslabah ukhrawiyyah dan maslahah dunyawiyyah sekaligus. Hal

\begin{tabular}{ll}
\hline 8 & Ibid, h. 20. \\
9 & Ibid, h. 20. \\
10 & Ibid, h. 9 \\
11 & Ibid, h. 14. \\
12 & Ibid, h. 9-10. \\
13 & Ibid, h. 14.
\end{tabular}


demikian harus melalui cara yang tidak merusak tatanan, baik secara keseluruhan maupun sebagian, baik menyangkut perkara darûriyyah, perkara hâjizyyah maupun perkara tahsiniyyah. Berdasarkan dari keterangan di atas terlihat dengan jelas bahwa sorang anak berhak memperoleh status dan hak perdata secara sah baik secara undang-undang peraturan hukum agama. Sebab memandang kepada hukum maslahat, artinya adalah lebih banyak mudratnya dari pada kebaikannya, seperti yang dikemukakan oleh al-Syâtibi. Oleh sebab itu penjelasan di atas maka jelas terlihat bahwa putusan Mahkamah Konstitusi, tentang status dan hak perdata anak lebih satu sisi lebih memandang kemaslahat. Sehingga Mahkamah Konstitusi (MK), menyatakan dengan tegas bahwa anak yang lahir diluar nikah mendapat hak dan keperdataan dari ayah yang menzinahinya walaupun tidak ada ikan nikah, dengan dibuktikan hasil dari medis yakni tes DNA.

Berangkat dari permasalah yang muncul tersebut, maka penulis ingin meneliti lebih jauh lagi tentang permasalahan tersebut dalam bentuk buku dengan judul: PROBLEMATIKA ANAK DI LUAR NIKAH DITINJAU DARI MAQASID AS-SYARI'AH 


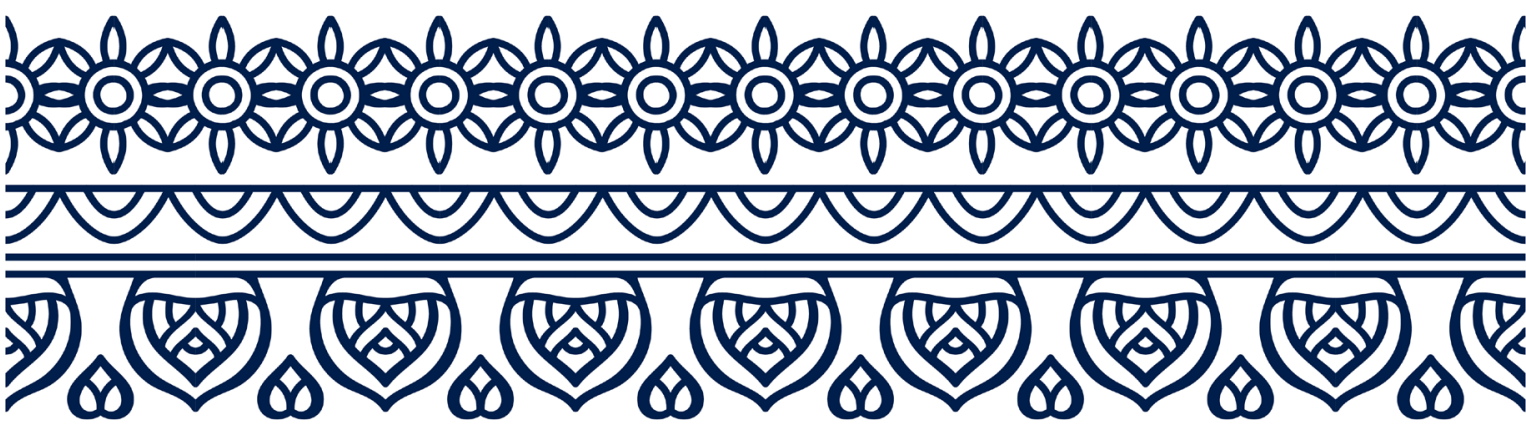

\section{BAGIAN II \\ MAQÂSHID AL-SYAR'IAH}

\section{A. Pengertian Maqâshid al-Syar'iah}

Maqashid al-syariah terdiri dari dua kata yaitu: maqashid dan al-syariah. Sebelum menjelaskan pengertian maqashid al-syariah secara istilah terlebih dahulu dijelaskan pengertiannya secara bahasa (lughawi). Apa itu maqashid dan apa itu syari'ah. Secara bahasa, maqashid jama' dari kata maqshid yang berarti kesulitan dari apa yang dituju atau dimaksud ${ }^{1}$. Secara akar bahasa, maqashid berasal dari kata qashada, yaqshidu, qashdan, qashidun, yang berarti keinginan yang kuat, berpegang teguh, dan sengaja ${ }^{2}$. Atau dapat juga diartikan dengan menyengaja atau bermaksud kepada (qashada ilaihi) ${ }^{3}$. Sebagaimana firman Allah SWT :

\section{"Allah lah yang menjelaskan jalan yang lurus". ${ }^{4}$}

Al Maqashid merupakan bentuk plural dari kata al maqsad, ia adalah masdar mim dari kata kerja qasada yaqsudu qasdan wamaqsadan. Kata al qashd 
dan al maqsud memiliki makna yang sama dan secara etimologi atau bahasa bisa berarti sbb:

Al qashd memiliki makna niat, maksud atau tujuan. Al qashd juga berarti kesederhanaan, adil dan seimbang sebagaimana Firman Allah swt :

"Dan sederhanalah kamu dalam berjalan dan lunakkanlah suaramu. Sesungguhnya seburuk-buruk suara ialah suara keledai"(Qs. Luqman:19).

Kata qashd maknanya secara harfiah berarti hemat. Ibnu Katsir menjelaskan, berjalanlah yang biasa saja tidak sangat lambat dan tidak sangat cepat, jalanlah yang biasa itu cara berjalan yang sopan. Dan rendahkan suaramu”, maknanya adalah janganlah berlebihan dalam berbicara dan jangan berlebihan mengangkatnya, makanya di dalam Al Qur'an disebutkan. Janganlah kamu meninggikan suaramu melebihi suara Nabi." Dan kemudian penutup ayat ini, "Sesunguhnya seburuk-buruk suara adalah suara himar. Ibn Katsir menjelaskan, disebutkan suara yang paling buruk adalah suara himar, ini menunjukan bahwa mengangkat suara yang paling keras itu bukan hanya tidak baik, tapi juga tercela. Inti dari ayat ini adalah bagaimana cara berkomunikasi dengan orang lain kemudian bagaimana cara berjalan, bagaimana cara kita menungkapkan katakata kita, dan bagaimana pula kita bersikap secara umum terhadap orang lain, kalau kita perhatikan akhlaq itu dibahas di belakang karena dakwah bil máruf itu akan efektif bilamana didukung dengan akhlaq yang mulia. ${ }^{5}$ Al qashd juga bisa diartikan dengan jalan yang lurus, mudah diraih dan tidak begitu jauh. Makna ini sesuai firman Allah swt :

"Dan hak bagi Allah swt (menerangkan) jalan yang lurus, dan di antara jalan-jalan ada yang bengkok. dan Jikalau Dia menghendaki, tentulah Dia memimpin kamu semuanya (kepada jalan yang benar)" (Qs. an Nabl:9)

Menurut al-Shabuni makna al-qashd adalah jalan yang lurus yakni adalah agama Islam Dan dari jalan yang lurus itu terdapat jalan yang bengkok atau condong dari yang hak dan orang yang berjalan di atasnya tidak sampai kepada Allah seperti orang-orang Yahudi, Nasrani, dan Majusi dan jika Allah

5 Ibn Katsir, Tafsir Ibn Katsir, (Mesir: Dar al I, 2010) h. 789-797 
menghendaki maka bisa saja Ia memberi hidayah kepada semua dengan iman atau jalan yang benar, namun manusia diberi pilihan untuk memilihj alannya. ${ }^{6}$ Selanjutnya, kata al-qashd terdapat dalam dalam firman Allah Swt, sebagai berikut:

Artinya: Kalau yang kamu serukan kepada mereka itu keuntungan yang mudah diperoleh dan perjalanan yang tidak seberapa jauh, Pastilah mereka mengikutimu, tetapi tempat yang dituju itu amat jauh terasa oleh mereka. mereka akan bersumpah dengan (nama) Allah: "Jikalau kami sanggup tentulah kami berangkat bersama-samamu." mereka membinasakan diri mereka sendiri dan Allah mengetahui bahwa Sesungguhnya mereka benarbenar orang-orang yang berdusta. (Qs. at Taubah : 42)

Sedangkan kata syariah berasal dari kata syara'a as-syai yang berarti menjelaskan sesuatu. Atau diambil dari asy-syar'ah dan asy-syariah dengan arti tempat sumber air yang tidak pernah terputus dan orang datang ke sana tidak memerlukan alat $^{7}$. Atau berarti juga sumber air, di mana orang ramai mengambil air. Selain itu al-syari'ah yang akar kata berasal dari kata syara'a, yasri'u, syar'an yang berarti memulai pelaksanaan suatu pekerjaan ${ }^{8}$. Dengan demikian al-syariah mempunyai pengertian pekerjaan yang baru mulai dilaksanakan. Syara'a juga berarti menjelaskan, menerangkan dan menunjukkan jalan. Syar'a lahum syar'an berarti mereka telah menunjukkan jalan kepada meraka atau bermakna sanna yang berarti menunjukkan jalan atau peraturan'. Jadi, secara bahasa syariah menunjukkan kepada tiga pengertian, yaitu sumber tempat air minum, jalan yang lurus dan terang dan awal dari pada pelaksanaan suatu pekerjaan.

Dengan mengetahui pengertian maqashid dan al-syariah secara bahasa, maka pengertian yang terkandung dalam istilah, yaitu tujuan-tujuan dan rahasia-rahasia yang diletakkan Allah dan terkandung dalam setiap hukum untuk keperluan pemenuhan manfaat umat. Atau tujuan dari Allah menurunkan

6 As-Shoubuni, Tafsir Ahkam jilid 2, h. 120.

7 Yusuf Al-Qardhawi, Fikih Maqashid Syari'ah, Alih Bahasa Arif Munandar Riswanto, (Jakarta: Pustaka al-Kautsar, 2007), h. 12

8 Hasbi Umar, Nalar Fiqih Kontemporer, (Jakarta: Gaung Persada Press, 2007), h. 36.

$9 \quad$ Ibid.h. 36 
syari'at, dimana menurut al-Syatibi adalah untuk mewujudkan kemashlahatan manusia di dunia dan akhirat ${ }^{10}$. Wahbah al-Zuhaili mengatakan bahwa maqashid al syariah adalah nilai-nilai dan sasaran syara' yang tersirat dalam segenap atau bagian terbesar dari hukum-hukumnya. Nilai-nilai dan sasaran-sasaran itu dipandang sebagai tujuan dan rahasia syariah, yang ditetapkan oleh al-syari dalam setiap ketentuan hukum ${ }^{11}$. Yusuf Al-Qardhawi mendefenisikan maqashid al-syariah sebagai tujuan yang menjadi target teks dan hukum-hukum partikular untuk direalisasikan dalam kehidupan manusia. Baik berupa perintah, larangan, dan mubah. Untuk individu, keluarga, jamaah, dan umat ${ }^{12}$. Atau juga disebut dengan hikmat-hikmat yang menjadi tujuan ditetapkannya hukum, baik yang diharuskan ataupun tidak ${ }^{13}$. Karena dalam setiap hukum yang disyari'atkan Allah kepada hambanya pasti terdapat hikmat ${ }^{14}$, yaitu tujuan luhur yang ada di balik hukum ${ }^{15}$.

Ulama Ushul Fiqih mendefinisikan maqashid al-Syariah dengan makna dan tujuan yang dikehendaki syara' dalam mensyari'atkan suatu hukum bagi kemashlahatan umat manusia. Maqashid al-Syariah di kalangan ulama ushul fiqih disebut juga asrar al-syariah, yaitu rahasia-rahasia yang terdapat di balik hukum yang ditetapkan oleh syara', berupa kemashlahatan bagi manusia, baik di dunia maupun di akhirat. Misalnya, syara'mewajibkan berbagai macam ibadah dengan tujuan untuk menegakkan agama Allah SWT ${ }^{16}$. Kemudian dalam perkembangan berikutnya, istilah maqashid al-alsyariah ini diidentik dengan filsafat hukum Islam ${ }^{17}$.

Sedangkan secara terminologis, maqashid mempunyai arti menghendaki sesuatu dan berpegangan teguh kepadanya (iradah al-syai wa al-azm alaihi). Sedangkan kata syariah berarti apa-apa yang ditentukan Tuhan kepada hamba-

10 Al-Syatibi, Al-Muwafaqat Fi Ushul al-Syari'ah, (Beirut: Dar al-Kutub al-IImiyah, 2003), I.h 3.

11 Wahbah al-Zuhaili, Ushul Figh Islami, (Damaskus: Dar al Fikri, 1986), II, h 225

12 Al-Qardhawi, op.cit, h. 17

13 Ibid. h. 18

14 Ibid. h. 18

15 Ibid. h. 19

16 A. Aziz Dahlan (ed), Ensiklopedi Hukum Islam, (Jakarta: PT Ichtiar Baru Van Hoeve, tt), III, h. 1108

17 Hasbi, op.cit., h. 120 
Nya melalui perantara nabi-Nya. Dari beberapa keterangan di atas terlihat dengan jelas bahwa yang dimaksud dengan maqashid al-Syariah ialah essensi atau hikmah yang terkandung dalam semua hukum syari'at yang telah ditetapkan Syari'(Allah Swt dan rasul-Nya) dan mencakup segala aspek hukum. Menurut S. Juhaya Praja, al-Maqashid as-Syariah dapat dijadikan pijakan dalam mengistimbatkan hukum. Sehingga bila ada kontradiksi antara al-Maqashid as-Syariah dengan firman Allah SWT, maka yang dijadikan dasar adalah al-Maqasihd as-Syariah. Adapun soal muamalah harus melalui pintu ijtihad tanpa terikat secara baku dalam al-Quran dan as-Sunnah ${ }^{18}$.

\section{B. Urgensi Maqâsidid al-Syarî’ah}

Pemahaman seorang mujtahid tentang maqashid al-syariah sangat penting. Karena hal ini akan membantunya ketika berijtihad yang akan membangun hukum-hukum syari'ah serta menjelaskan aspek-aspek hukum tersebut ${ }^{19}$. Ibnu Asyur mengatakan sebagaimana yang dikutip oleh Ahsan Lihasanah, bahwa wajib bagi para ulama untuk mengetahui 'illat-illat tasyri'serta tujuannya secara tersurat (zahir) maupun tersirat (bathin).

Jika ditemukan sebagian hukum yang tersembunyi, karena mereka sudah mengetahui tujuannya, baik itu secara tersurat maupun tersirat, niscaya mereka mengerti dalam memberikan fatwa-fatwa hukum ${ }^{20}$. Pemahaman-pemahaman tersebut meliputi: pertama, mengetahui perkataan-perkataan dan faedah dalildalil dalam bentuk lughawi dan kaidah-kaidah lafziyah untuk menemukan hukum-hukum fiqh; kedua, membahas dalil-dalil yang bertentangan dari yang sudah dinashakhkan, atau mengaitkan tujuan pengamalannya, atau menjelaskan hubungan dalil yang satu dengan dalil yang lain; ketiga, Qiyas digunakan jika aqwal syara' (perkatan-perkataan syara) belum ditemukan hukumnya; keempat, memberikan suatu hukum yang tidak ada nash dan qiyas didalamnya; kelima, menemukan hukum-hukum syari'ah yang bersifat ta'abbudi jika sekiranya tidak

18 Juhaya S. Praja, Teori Hukum Dan Aplikasinya, (Bandung: Pustaka Setia, 2011), h. 78

19 Ahsan, Op, Cit, h.27

20 Ibid, h. 27 
ada pembahasan tentang illat-illat hukum ${ }^{21}$.

Dengan demikian, maqashid al-syariah ini akan membantu para mujtahid dalam menentukan kedhabitan aturan-aturan hukum serta mashlahah dan mafsadah, pengetahuan tentang maqâsid al-Syarîah, dan pengetahuan tentang illat-illat hukum. Dalam upaya mengembangkan pemikiran hukum Islam, terutama dalam memberikan pemahaman dan kejelasan terhadap berbagai persoalan hukum kontemporer, para mujtahid perlu mengetahui tujuan pensyari'atan hukum Islam. Selain itu, tujuan hukum perlu diketahui dalam rangka mengenal pasti, apakah suatu ketentuan hukum masih dapat diterapkan terhadap suatu kasus tertentu atau karena adanya perubahan struktur sosial, hukum tersebut tidak dapat lagi dipertahankan. Dengan demikan, pengetahuan mengenai maqashid al-Syariah menjadi kunci bagi keberhasilan mujtahid dalam ijtihadnya ${ }^{22}$. Karena mengingat, hukum itu selalu berkembang sesuai dengan perkembangan tempat, zaman, dan keadaan. Seperti hukum perempuan yang keluar dalam perjalanan (musafir) tanpa disertai muhrimnya dan perjalanan tersebut bukanlah perjalanan dalam bermaksiat kepada Allah. Hal ini pada zaman Rasulullah, beliau sangat melarangnya karena takut akan timbul fitnah dan keselamatan perempuan tersebut. Namun seiring dengan berkembangnya tempat, zaman, dan keadaan. Para perempuan bisa berjalan dengan sendiri dengan aman dan nyaman tanpa ada merasa takut gangguan, maka hukum ini tentunya juga akan berubah. Atau ada suatu kasus yang dalil untuk menetapkan hukumnya tidak ditemukan dalam al-Qur'an dan al-Sunnah, di sinilah peran maqashid al-Syariah untuk memecahkan hal-hal tersebut dengan berlandaskan kepada kemashlahatan. Khusus dalam menghadapi persoalan-persoalan fiqih kontemporer, terlebih dahulu dikaji secara teliti hakikat dari masalah tersebut. Penelitian terhadap suatu kasus yang akan ditetapkan hukumnya sama pentingnya dengan penelitian terhadap sumber hukum yang akan dijadikan dalilnya. Dengan kata lain, kandungan nash harus diteliti secara cermat, termasuk tujuan pensyari'atan hukum tersebut ${ }^{23}$. Setelah itu baru dilakukan kategorisasi masalah (tanqih al-manat), apakah ayat atau hadits tertentu layak dijadikan dalil bagi 
kasus baru tersebut. Mungkin ada suatu kasus baru yang hampir sama dengan kasus hukum yang terdapat di dalam al-Qur'an dan al-hadits. Jika ternyata tidak ditemukan kesamaan atau kemiripan antara persoalan baru dengan kasus hukum yang ada pada kedua sumber hukum tersebut, maka konsekuensinya persoalan baru tersebut tidak dapat disamakan hukumnya dengan kasus hukum yang terdapat di dalam al-Qur'an dan al-Sunnah. Di sinilah letak urgen atau pentingya pengetahuan tentang maqashid al-Syariah (tujuan pensyari'atan hukum) dalam hukum Islam ${ }^{24}$.

\section{Pembagian Maqâshid al-Syarî’ah}

Dalam maqashid al-syariah tentu harus menempatkan buah pikir al-Syâtibi sebagai fokus perhatian, karena beliaulah yang merupakan icon bagi konsep maqashid al-syariah dalam jagat wacana teori hukum Islam. Dalam karyanya al-Muwâfaqât, al-Syâtibi menggunakan istilah yang berbeda-beda sehubungan dengan isu maqashid al-syariah, yakni berupa istilah maqâshid al-Syarìah, almaqâshid al-Syar'iyyah fi al-Syarî̀ah, dan maqâssid min Syar'i al-hukm. Meskipun demikian, semua itu mengandung pengertian yang sama, yakni tujuan, arah sasaran, dan dasar pijakan bagi hukum yang ditetapkan oleh Allah swt. ${ }^{25}$

Uraian berikut ini sepenuhnya merujuk kepada magnum opus al-Syâttibi tersebut. Dalam proposisi utama yang diutarakannya, al-Syâtibi menegaskan bahwa sesungguhnya Syariah/hukum Islam itu bertujuan mewujudkan maslahah bagi manusia, baik di dunia maupun di akhirat. ${ }^{26}$ Pada bagian lain, beliau mengungkapkan: "Hukum-hukum ditetapkan untuk mewujudkan maslahah bagi umat manusia.” Dengan demikian, jelaslah bahwa al-Syâtibi memandang

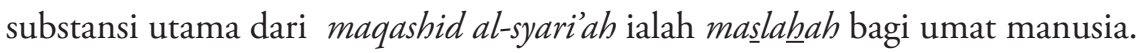
Oleh karena itu, isu masla $\underline{h} a h$ menjadi fokus analisis penting dalam rangka memahami maqâshid al-Syarîah. Oleh sebab itu, Imam Syathibi membagi alMaqashid ini kepada dua bagian penting yakni Maksud Syari' (qashdu al-syari) dan Maksud Mukallaf (qashdu al-mukallaf). Maksud Syari' kemudian dibagi

24 Ibid., h. 121.

25 Abu Ishââ Ibrâhîm al-Syâtibi, Op.cit, I, Juz ke-2, h. 3.

26 Ibid, h. 4. 
lagi menjadi 4 bagian yaitu:

\section{Qashdu al-Syari' fi Wadh'i al-Syari'ah}

Qashdu al-Syari' fi Wadh'i al-Syari'ah (maksud syari dalam menetapakan syariat). Dalam bagian ini ada 13 permasalahan yang dikemukakan. Namun semuanya mengacu kepada suatu pertanyaan: "Apakah sesungguhnya maksud syari dengan menetapkan syari'atnya itu?” Menurut Imam Syathibi, Allah menurunkan syariat (aturan hukum) tiada lain selain untuk mengambil kemaslahatan dan menghindari kemadaratan (jalbul mashalih wa dar'ul mafasid). Dengan bahasa yang lebih mudah, aturan-aturan hukum yang Allah tentukan hanyalah untuk kemaslahatan manusia itu sendiri. Syathibi kemudian membagi maslahat ini kepada tiga bagian penting yaitu dharuriyyat (primer), hajiyyat (skunder) dan tahsinat (tersier, lux).

Maqashid atau Maslahat Dharuriyyat adalah sesuatu yang mesti adanya demi terwujudnnya kemaslahatan agama dan dunia. Apabila hal ini tidak ada, maka akan menimbulkan kerusakan bahkan hilangnya hidup dan kehidupan ${ }^{27}$ seperti makan, minum, shalat, shaum dan ibadah-ibadah lainnya. Yang termasuk maslahat atau maqashid dharuriyyat ini ada lima yaitu: agama (al-din), jiwa (al-nafs), keturunan (an-nasl), harta (al-mal) dan aqal (al-aql). ${ }^{28}$

Cara untuk menjaga yang lima tadi dapat ditempuh dengan dua cara yaitu:

1. Dari segi adanya (min nabiyyati al-wujud) yaitu dengan cara manjaga dan memelihara hal-hal yang dapat melanggengkan keberadaannya

2. Dari segi tidak ada (min nahiyyati al-'adam) yaitu dengan cara mencegah hal-hal yang menyebabkan ketiadaannya.

\section{Qashdu al-Syari' fi Wadh'I al-Syari'ah lil Ifham}

\section{a. Kemashlahatan}

$27 \quad$ Ibid, h. 7

28 Ibid, h. 8. 
Islam sebagai agama samawi mempunyai kitab suci al-Qur'an sebagai sumber hukum utama, al-Qur'an mengandung berbagai ajaran. Di kalangan ulama ada yang membagi kepada tiga kelompok besar, yaitu aqidah, khuluqiyah, dan amaliyah. Aqidah berkaitan dengan dasar-dasar keimanan, khluqiyah berkaitan dengan etika, dan amaliyah berkaitan dengan aspek-aspek hukum yang muncul dari aqwal (ungkapan-ungkapan) dan af'al (perbuatan-perbuatan manusia). Kelompok terakhir ini dalam sistematika hukum Islam dibagi ke dalam dua besar, yaitu ibadat (pola hubungan manusia dengan tuhan) dan muamalah (pola hubungan manusia dengan manusia) ${ }^{29}$. Sebagai sumber ajaran, al-Qur'an tidak memuat aturan-aturan yang terperinci tentang ibadah dan muamalah. Dari 6360 ayat al-Qur'an hanya terdapat 368 ayat yang berkaitan dengan aspek-aspek hukum ${ }^{30}$.

Dari sini dapat dipahami bahwa sebagian besar masalah-masalah hukum Islam, oleh tuhan hanya diberikan dasar-dasar dalam al-Qur'an. Bertitik tolak dari prinsip-prinsip ini, dituangkan pula lewat hadits Rasulullah SAW. Berdasarkan atas dua sumber inilah kemudian, dari aspek hukum terutama dalam konteks muamalah dikembangkan oleh ulama di antaranya al-Syatibi (W.790) yang telah mencoba mengembangkan pokok atau prinsip yang terdapat dalam dua sumber ajaran Islam itu dengan mengaitkan dengan maqashid al-syariah ${ }^{31}$. Dalam karyanya, al-muwafaqat, Asy-Syatibi menggunakan kata yang berbeda-beda yang berkaitan dengan maqâshid al-Syarî̀ah. Kata tersebut adalah maqâshid al-Syarî̀ah, ${ }^{32}$ al-maqashid al-alsyari'ah fi alsyariah, ${ }^{33}$ dan maqashid min syar'i hukm. ${ }^{34}$ Pada prinsipnya, penemaan kata-kata yang berbeda tersebut mengandung pengertian yang sama,

29 Abd. al-Wahab Khallaf, Ilmu Ushul Figh, (Kairo: Dar al-Kawatiyyah, 1998), h. 32.

30 Harun Nasotion, Islam Ditinjau Dari Berbagai Aspeknya, (Jakarta: UI-press, 1984), h. 7.

31 Mustamin Giling, "Kedudukan Maqashid al-Syari'ah Dalam Agama”, Stadium: Kajian Sosial, Agama, Hukum, dan Pendidikan, Vol. 1. No. 2, (2003), h. 112 Al-Syatibi, Op.Cit, I, h. 21.

33 Ibid., I, h 23.

34 Ibid., II, h 374. 
yaitu tujuan hukum yang diturunkan Allah SWT. ${ }^{35}$ Syari' at Islam datang sebagai rahmat bagi umat manusia, memberikan nasehat bahkan penyembuh terhadap apa-apa yang terdapat di dalam hati, karena itu Islam dalam pelaksanaan hukum-hukumnya terbagi kepada tiga segi (unsur). Pertama, sebagai pendidikan secara individu untuk mampu menciptakan kebaikan secara kolektif; kedua, untuk melaksanakan keadilan dalam kehidupan masyarakat Islam secara keseluruhan yang nantinya kedudukan manusia sama di depan undang-undang dan putusan. Sehingga tidak dibedakan lagi antara si kaya dan si miskin, yang kuat dan yang lemah; ketiga, dari aspek hukum Islam, esensi dan substansinya yaitu kemashlahatan, ${ }^{36}$ sebab apa yang disyari'atkan Islam lewat nash di dalamnya terdapat hakekat maslahat. ${ }^{37}$

Setiap seruan Allah dapat dipahami oleh akal, kenapa Allah menyuruh, tentunya ada kemashlahatan untuk umat manusia, apakah dijelaskan sendiri alasannya atau tidak, maupun menjelaskan kenapa suatu perbuatan dilarang, tentunya juga ada kemaslahatan untuk manusia agar manusia tidak masuk kedalam kehancuran. Sebagaimana yang dijelaskan al-Syatibi dalam kitab al-Muwafaqat-Nya:

\section{هذه الشريعة وضعت لتحقيق مقاصد الشارع في قيام مصالحهم في

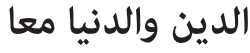

35 Giling, Op, Cit, h. 117.

36 Dalam bahasa Arab, mashlahah (jamaknya mashalih) merupakan sinonim dari kata manfa'at dan lawan kata dari mafsadat (kerusakan). Secara majaz, kata ini juga dapat digunakan untuk perbuatan yang mengandung manfaat. Kata manfaat sendiri selalu diartikan dengan ladzdzaz (rasa enak) dan upaya mendapatkan atau mempertahankannya (Husain Hamid Hassan. Nazariyah al-Mashlahah fi al-Fiqh alIslami. (Kairo: al-Mutanabbi, 1981), h. 4). Sementara al-Khawarizmi sebagai mana yang dikutip oleh Wahbah al-Zuhaili mengatakan bahwa mashlahah adalah menjaga tujuan syara' dengan menolak fasad (kehancuran) dari penciptaan. (Wahbah alZuhaili, Ushul al-Figh al-Islami, Jilid II, h. 37). Dalam kajian syari'at, kata mashlahat dipakai sebagai istilah untuk mengungkapkan perngertian yang khusus, meskipun tidak lepas dari arti aslinya. Al-Ghazali mengatakan bahwa mashlahat adalah menarik manfaat atau menolak mudharat, secara istilah ia menjelaskan adalah pemeliharaan tujuan syara', yakni agama, jiwa, akal, dan harta. (al-Ghazali, al-Musthashfa Min IImi al-Ushul, (Beirut: Muassasah al-Risalah, 1997), I, h. 417). 
Kalijunjung Hasibuan SHI., M.Sy dan Dr. Ali Hamzah, M.Ag

"Syariat itu bertujuan untuk kemashlahatan manusia (hamba), cepat ataupun lambat secara bersamaan, dan ajakan ini pasti berasal petunjuk tuhan, apakah itu membawa kemashlahatan (shihhah) ataupun kehancuran (fasad) '38.

Apabila diteliti pernyataan al-Syatibi ini, dapatlah dipahami bahwa kandungan maqashid al-alsyariah adalah untuk kemashlahatan manusia. Oleh karenanya, bisa dikatakan bahwa seluruh ajaran yang tertuang dalam Al-Quran maupun al-Sunnah menjadi dalil adanya maslahat. Meskipun sumber syara' tersebut tidak semuanya berbicara mengenai kemashlahatan secara langsung, akan tetapi ada beberapa dalil yang bisa mengindikasikan terhadap eksistensi maslahat dalam syari'at Islam. Oleh karenanya, bisa dikatakan bahwa seluruh ajaran yang tertuang dalam Al-Quran maupun al-Sunnah menjadi dalil adanya maslahat. Meskipun sumber syara' tersebut tidak semuanya berbicara mengenai kemashlahatan secara langsung, akan tetapi ada beberapa dalil yang bisa mengindikasikan terhadap eksistensi maslahat dalam syari'at Islam. Secara umum, alasan yang dikemukakan jumhur ulama dalam menetapkan maslahat sebagai hujjah dalam menetapkan hukum, antara lain adalah: ${ }^{39}$

1. Hasil induksi terhadap ayat atau hadits yang menunjukkan bahwa setiap hukum mengandung kemaslahatan bagi umat manusia.

2. Kemaslahatan manusia akan senantiasa dipengaruhi perkembangan tempat, zaman, dan lingkungan mereka sendiri. Apabila syariat Islam terbatas pada hukum-hukum yang ada saja, maka akan membawa kesulitan bagi umat manusia.

3. Jumhur ulama juga beralasan pada beberapa perbuatan sahabat yang seringkali berbuat dan membuat kebijakan dengan berdasar pada maslahat.

38 Asy-syatibi, al-Muwafaqat Fi Ushul al-Syari'ah, II, h. 4

39 Op.Cit, h. 1147. 
Bertitik tolak dari pandangan bahwa semua kewajiban (taklif) diciptakan dalam rangka merealisasikan kemashlahatan hamba. Dan ini juga menunjukkan bahwa ta'lil peletakan al-syariah dari sisi kuantiti (jumlah), dan menghubungkannya dengan kemashlahatan manusia di dunia dan akhirat. ${ }^{40}$ Dan tujuan syara adalah untuk kemashlahatan yang terdiri dari atas lima pengayoman yaitu menjaga agama, jiwa, keturunan, harta, dan akal manusia. Sehingga menurut al-Ghazali, segala sesuatu yang mengayomi lima hal tersebut, maka itulah mashlahah, dan segala susuatu yang menghancurkan lima hal tersebut, maka itulah mafsadah. ${ }^{41}$

\section{b. Sesuatu yang Harus Dipahami}

Maqashid al-Syarîah dalam arti maqashid al-syari' mengandung empat aspek, salah satunya adalah sebagai sesuatu yang harus dipahami. Aspek ini berkaitan dengan dimensi bahasa agar syari'at itu dapat dipahami, sehingga dapat dicapai kemashlahatan yang dikandungnya. Metode memahami maqashid al-Syarîah diidentik dengan pengetahuan tentang pengkajian kandungan al-Qur'an dan al-Sunnah. Secara faktual, nash terdiri dari huruf-huruf arab atau bahasa arab dengan sejumlah kaidahnya, maka salah satu cara untuk memahami maqashid al-alsyari'ah adalah pemahaman kebahasaan. Namun pendekatan kebahasaan saja tidaklah cukup, sebab syari'at itu sering kali memakai bahasa di luar pengertian lafaz dan kaedah kebahasaan.

Memahami hukum secara benar hanya bisa terjadi apabila benarbenar memahami uslub bahasa arab dan teori dalalah di dalamnya. Dan dipahami pula dalil-dalil yang menunjukkan bahwa lafaz-lafaz tersebut berbentuk mufrod (singular) atau murokkab (tersusun) ${ }^{42}$. Para ulama ushul fiqh sangat memperhatikan uslub-uslub bahasa arab, ungkapan, dan mufrodat (sinonim)-nya. Dari hasil research

$40 \quad$ Ahsan, Op.Cit, h. 39.

41 Al-Ghazali, al-Musthashfa min IImi al-Ushul, I, h. 417.

42 Abdul Wahhab Khallaf, Kaidah-Kaidah Hukum Islam, (Jakarta: PT. Raja Grafindo Persada, 2002), h. 219. 
(istiqra') dan ketetapan para ulama bahasa, maka mereka mengambil kaidah-kaidah dan batasan-batasan lalu menjaganya, sehinggga mereka bisa memahami hukum-hukum dari nash-nash syar'iyah dengan pemahaman yang benar yang sesuai dengan pemahaman orang arab. Dengan kaidah-kaidah dan batasan itu pula mereka bisa menjelaskan nash-nash yang masih bersifat samar-samar, mentarjihkan nash yang bersifat kontradiksi, mentakwili nash yang ada petunjuk (dalil) untuk ditakwili, dan lain-lain yang ada hubungannya dengan pengambilan hukum-hukum dari nash ${ }^{43}$. Oleh karena itu, para mujtahid dalam menggali hukum yang terkandung dalam syari'at sering keluar dari konteksss bunyi lafaz dan memakai teks dengan arti baru. Cara ini disebut dengan metode ma'nawi. ${ }^{44}$

1. Mamahami al-syariah melalui bunyi lafaz.

Ada dua kemungkinan pemahaman disebabkan oleh dua hal yaitu:

a. Lafaz itu digunakan untuk dua maksud dengan pemahaman yang sama, misalnya kata quru'(QS. al-Baqarah : 228) yang berarti suci atau haid. Kata 'aqdatu al-nikah (QS. al-Baqarah: 237) yang mengandung arti wali atau istri. Kemudian kata "lamastumu" ${ }^{45}$ (QS. an-Nisa : 43) dapat berarti bersetubuh atau bersentuh kulit.

b. Lafaz yang menggunakan nama atau kiasan yang menurut lahirnya mendatangkan keraguan. Keraguan itu disebabkan penggunaan sifat yang ada pada manusia untuk Allah SWT., padahal Allah SWT tidak sama dengan makhluknya. Umpamanya penggunaan kata "wajah" atau "muka" untuk Allah (al-Rahman: 27) dan penggunaan kata "bersemayam" untuk Allah (QS. Yunus : 3). 
Berdasarkan kedua bentuk pemahaman lafaz tersebut, maka semua mujtahid tidak dapat keluar dari konteks lafaz, mereka hanya berbeda dalam hal sejauh mana kedekatan ijtihadnya dengan lafaz. Masalah apapun yang timbul dalam kehidupan umat manusia, tidak mungkin memberi nilai syari'at tanpa menghubungkan dengan bunyi lafaz, baik dikaitkan dengan arti majazi maupun arti substansinya.

2. Memahami al-syariah melalui makna lafaz

Yang dimaksud dengan makna lafaz di sini ialah makna secara hakiki ${ }^{46}$ dan majazi ${ }^{47}$ termasuk makna musytarak. Misalnya, QS alMaidah (5) : 33 :

"Sesungguhnya pembalasan terhadap orang-orang yang memerangi Allah dan Rasulnya dan membuat kerusakan di muka bumi, hanyalah mereka dibunuh atau disalib atau dipotong tangan dan kaki mereka dengan bertimbal balik, atau dibuang dari negeri (tempat kediaman".

Kata "dibuang" (auyanfu) pada ayat tersebut mengandung arti hakiki dan majazi, arti hakiki ialah "mereka dikeluarkan dari negeri mereka ke negeri lain”. Sedangkan arti majazi adalah "mereka dimasukkan ke dalam penjara". Imam Abu hanifah memilih arti hakiki "diusir" ke negeri lain. ${ }^{48}$

3. Memahami al-syariah melalui makna di luar nash

Metode memahami syari'at melalui makna di luar nash yaitu metode istihsan dan al-mashlahah al-Mursalah.

$46 \quad$ Hakikat adalah lafaz yang sengaja untuk memberi arti yang sesuai dengan pengistilahan dibidang ilmunya. Mukhtar Yahya dan Fatchurrahman, Dasar-Dasar Pembinaan Hukum Islam, (Bandung: PT al-Ma'arif, 1986), h. 259.

47 Majazi adalah suatu lafaz yang digunakan untuk suatu arti yang lafaz itu diciptakan untuk lafaz tersebut atau lafaz pinjaman. Ibid. h. 259

48 Ibrahim Husen, Memecahkan Permasalahan Hukum Baru; ljtihad Dalam Sorotan, (Bandung: Mizan, 1988), h. 32. 
Kalijunjung Hasibuan SHI., M.Sy dan Dr. Ali Hamzah, M.Ag

\section{a. Istihsan}

Istihsan secara bahasa adalah kata bentuk (musytaq) dari al-hasan (apapun yang baik dari sesuatu). Istihsan sendiri kemudian berarti kecenderungan seseorang pada sesuatu karena menganggapnya lebih baik, dan ini bisa bersifat lahiriah ( hissiy) ataupun maknawiah, meskipun hal itu dianggap tidak baik oleh orang lain. ${ }^{49}$ Secara istilah, al-Ghazali mengatakan bahwa istihsan adalah Dalil yang terbetik dalam diri seorang mujtahid, namun tidak dapat diungkapkannya dengan katakata. $^{50}$

Adapun istihsan menurut ulama ushul ialah berpindahnya seorang mujtahid dari tuntutan qiyas jali (qiyas nyata) kepada qiyas khafi (qiyas samar) atau dari hukum kulli kepada hukum pengecualian, karena ada dalil yang menyebabkan ia mencela akalnya, dan dimenangkan perpindahan ini. ${ }^{51}$ Maksudnya, apabila seorang mujtahid menghadapi suatu perkara yang tidak ada nash yang menetapkan hukumnya, sedang untuk mencari hukum terdapat dua jalan yang berbeda-beda, jalan yang satu sudah jelas dan yang lainnya masih samar-samar, yakni dapat menetapkan hukum dan dapat pula menetapkan hukum yang lain, padahal pada diri mujtahid tersebut terdapat suatu dalil yang dapat digunakan untuk mentarjihkan jalan yang samar-samar, lalu ia meninggalkan jalan yang nyata tersebut untuk menempuh jalan yang samar-samar tersebut. Demikian pula bila ia menetapkan suatu hukum, kemudian setelah ia mendapatkan dalil yang lain yang mengecualikan suatu hukum dari dalil kulli tersebut, maka ia menetapkan hukum lain yang berbeda dengan hukum yang ditetapkan oleh dalil-dalil kulli itu. Kedua jalan inilah yang dimaksud

49 Ibn Manzur, Op.Cit, II,h. 879.

50 Op.Cit, h 138.

$51 \quad$ Khallaf, Op.Cit, h. 117 
dengan istihsan. ${ }^{52}$

Istihsan ada dua macam: Petama, mentarjihkan qiyas yang tidak nyata (samar-samar) atas qiyas yang nyata berdasarkan suatu dalil. Hal semacam ini menurut kalangan hanafiyah disebut dengan istihsan qiyas atau qiyas khafi. Contoh, Sisa minum dari burung yang busa menurut istihsan adalah suci, sedangkan menurut qiyas adalah najis. ${ }^{53}$

Kedua, Mengecualikan hukum juzizyah dari hukum kuliyah dengan suatu dalil. Hal semacam ini menurut kalangan hanafiyah disebut dengan istihsan darurat. Sebab penyimpangan dari hukum tersebut adalah karena darurat atau karena suatu kepentingan yang mengharuskan adanya penyimpangan dengan maksud untuk menghadapi keadaan yang mendesak atau menghindari kesulitan. Contoh, syara' melarang mengadakan perikatan dan memperjual belikan barang-barang yang belum ada pada saat perikatan. Tetapi menurut istihsan, syara' memberikan rukhsah muamalat tersebut dengan diperkenankan menjalankan salam $^{54}$ dan istishna ${ }^{55}$. Keduanya adalah perikatan dalam bentuk lintas perdagangan, tetapi barang yang diperdagangkan belum terwujud pada saat perjanjian dibuat. Hukum kulli pada cohtoh ini adalah tidak sahnya memperjualbelikan barang yang belum berwujud pada saat perikatan terjadi. Tetapi oleh karena perikatan itu sangat dibutuhkan dan sudah menjadi kebiasaan dalam masyarakat, maka dikecualikanlah dari hukum kulli tersebut suatu hukum juz'i, yaitu masalah istishna'. Dengan kata lain, segi istishsannya ialah kebutuhan dan kebiasaan

52 Mukhtar dan Fatchurrahman, Dasar-Dasar Pembinaan Hukum Islam, h. 100-101.

53 Ibid.,h.102-102.

54 Salam adalah jual beli dengan pembayaran lebih dulu, tetapi barangnya dikirim kemudian.

55 Istishna' adalah memesan untuk dibuatkan sesuatu atau penjualan inden 
Kalijunjung Hasibuan SHI., M.Sy dan Dr. Ali Hamzah, M.Ag

dalam masyarakat. ${ }^{56}$

\section{b. Al-Mashlahah al-Mursalah}

Secara etimologi, mashlahah sama dengan manfaat, baik dari segi lafal maupun makna. Mashlahah juga berarti manfaat atau suatu pekerjaan yang mengandung manfaat. ${ }^{57}$ sedangkan al-mursalah adalah isim maf'ul (objek) dari fi'il madhi (kata dasar) dalam bentuk tsulasi "rasala" dengan penambahan huruf alif di awalnya sehingga menjadi "arsala". Secara bahasa artinya "terlepas" atau dalam arti mutlaqah (bebas). Kata lepas dan bebas di sini dihubungkan dengan kata mashlahah maksudnya adalah terlepas atau bebas dari keterangan yang menunjukkan boleh atau tidak bolehnya dilakukan. ${ }^{58}$

Secara istilah, mashlahah al-mursalah adalah suatu kemashlahatan yang tidak ditetapkan oleh syara' sesuatu hukum untuk mewujudkannya dan tidak pula terdapat suatu dalil syara' yang memerintahkan untuk memperhatikannya atau mengabaikannya. ${ }^{59} \mathrm{Hal}$ ini muncul setelah wahyu selesai diturunkan serta tidak ada dalil yang memerintah agar diperhatikan atau tidak. ${ }^{60}$ Misalnya menghimpun dan menulis al-Qur'an dalam satu mushaf. Baik nash dari al-Qur'an maupun hadits tidak memerintahkan dan tidak pula melarang hal tersebut. Tapi perbuatan semacam ini sangat mendatangkan manfaat bagi kaum muslimin, maka apa yang dirintis oleh Abu Bakar dan sahabat-sahabat yang lain dalam masalah tersebut merupakan mashlahah mursalah. Demikian juga halnya seperti surat nikah yang diadakan oleh Negara sebagai bukti sahnya perkawinan, mengadakan lembaga pemasyarakatan

$56 \quad$ Ibid,h. 102-103.

57 Ibnu Manzur, Op.Cit, IV, h. 2479

58 Totok Jumanto dan Samsul Munir Amin, Kamus Istilah Ushul Fikih, (Jakarta: Amzah, 2005), h. 203.

59 Abdul Wahhab Khallaf, Op.Cit, h. 85.

$60 \quad$ Ibid.h. 85 
(penjara) dan mencetak mata uang sebagai alat pertukaran resmi. Hal semacam ini tidak ada nash yang menyuruhnya dan tidak ada pula nash yang melarang, itu dimaksud untuk muwujudkan kemashlahatan dan mempermudah urusan dalam kehidupan. Maksud syari'at Islam itu tidak lain untuk mewujudkan kemashlahatan manusia, yakni menarik manfaat dan menolak mafsadat, dan menghilangkan kesusahan. Kemashlahatan manusia tidak terbatas macamnya dan tidak terhitung jumlahnya. ${ }^{61}$

1). Objek Maslahah al-Mursalah

Adapun yang menjadi objek al-maslahah almursalah adalah kejadian atau peristiwa yang perlu ditetapkan hukumnya, tetapi tidak ada satupun nash (alQur'an dan al-Hadits) yang dapat dijadikan dasar. Prinsip yang disepakati oleh kebanyakan pengikut mazhab yang ada dalam fikih. Menurut Imam al-Qarafi athThusi sebagaimana yang dikutip oleh Totok Jumantoro bahwa mashlahat al-Mursalah itu sebagai dasar untuk menetapkan hukum dalam bidang muamalah dan semacamnya, sedangkan dalam soal ibadah adalah Allah SWT yang menetapkan hukumnya, karena manusia tidak sanggup mengetahui dengan lengkap hikmah ibadah tersebut. ${ }^{62}$

2). Kehujjahan Maslahah al-Mursalah

Ulama Malikiyah dan Hanabilah menerima alMaslahah al-Mursalah sebagai dalil hukum, bahkan mereka dianggap sebagai ulama fikih yang paling banyak dan luas penerapannya. Untuk menjadikan al-Maslahah al-Mursalah sebagai dalil, ulama malikiyah dan Hanabilah

61 Ibid., h. 105-106.

62 Totok dan Amin, Op.Cit, h. 205. 